\title{
Network Protein Interaction in Parkinson's Disease and Periodontitis Interplay: A Preliminary Bioinformatic Analysis
}

\author{
João Botelho ${ }^{1,2, *(\mathbb{D})}$, Paulo Mascarenhas ${ }^{2,3}$, José João Mendes ${ }^{2} \mathbb{D}$ and Vanessa Machado ${ }^{1,2} \mathbb{D}$ \\ 1 Periodontology Department, Clinical Research Unit (CRU), Centro de Investigação Interdisciplinar Egas \\ Moniz (CiiEM), Instituto Universitário Egas Moniz (IUEM), 2829-511 Caparica, Portugal; \\ vmachado@egasmoniz.edu.pt \\ 2 Evidence-Based Hub, Clinical Research Unit (CRU), Centro de Investigação Interdisciplinar Egas \\ Moniz (CiiEM), Instituto Universitário Egas Moniz (IUEM), 2829-511 Caparica, Portugal; \\ pmascarenhas@egasmoniz.edu.pt (P.M.); jmendes@egasmoniz.edu.pt (J.J.M.) \\ 3 Center for Medical Genetics and Pediatric Nutrition Egas Moniz, Instituto Universitário Egas Moniz (IUEM), \\ 2829-511 Caparica, Portugal \\ * Correspondence: jbotelho@egasmoniz.edu.pt
}

Received: 29 September 2020; Accepted: 21 November 2020; Published: 23 November 2020

\begin{abstract}
Recent studies supported a clinical association between Parkinson's disease (PD) and periodontitis. Hence, investigating possible interactions between proteins associated to these two conditions is of interest. In this study, we conducted a protein-protein network interaction analysis with recognized genes encoding proteins with variants strongly associated with PD and periodontitis. Genes of interest were collected via the Genome-Wide Association Studies (GWAS) database. Then, we conducted a protein interaction analysis, using the Search Tool for the Retrieval of Interacting Genes/Proteins (STRING) database, with a highest confidence cutoff of 0.9 and sensitivity analysis with confidence cutoff of 0.7 . Our protein network casts a comprehensive analysis of potential protein-protein interactions between PD and periodontitis. This analysis may underpin valuable information for new candidate molecular mechanisms between PD and periodontitis and may serve new potential targets for research purposes. These results should be carefully interpreted, giving the limitations of this approach.
\end{abstract}

Keywords: Parkinson's disease; periodontitis; periodontal disease; protein-protein network interaction; bioinformatics

\section{Introduction}

Parkinson's disease (PD) is the second most frequent neurodegenerative condition, affecting primarily the central nervous system [1]. PD is clinically characterized by motor and non-motor symptoms, though its clinical onset and progression differ [2], and ultimately lead to disability and poor quality of life [3]. PD is age-dependent and is more prevalent in men [4,5]. The cause of PD is still unknown, however, a recent Mendelian randomization research reported 12 exposures and risk of PD [6]. Further, the role of inflammation in PD has been widely investigated $[7,8]$.

Periodontitis is a chronic dysbiotic and inflammatory disease of the periodontium and one of the most prevalent diseases worldwide [9,10]. This condition presents inflamed gum and alveolar bone loss surrounding the teeth and may cause their loss [11]. Periodontitis has been highly associated with several systemic conditions, for instance, diabetes [12], cardiovascular diseases [13,14], fertility-related conditions [15,16], rheumatic diseases [17] or Alzheimer's disease [18-20]. In most of these diseases, periodontitis shapes its influence through its chronic inflammatory burden and systemic bacteria spread. 
The interplay between PD and periodontitis is still scarce, but a number of studies have revealed that the associated motor impairments and cognitive decline may hamper oral hygiene and deteriorate oral health [21,22]. Moreover, PD individuals seem to be at high risk of developing periodontitis [23-27], and this may lead to systemic leukocytosis [28]. Moreover, a nationwide study concluded that people with periodontitis were at more risk to develop PD [29], and one of the possible reasons may be genetic interactions; thus, investigating such a genetic relation would be of great research interest.

Studying possible biological mechanisms between these two diseases could be fruitful towards unexplored ways, and therefore bioinformatics is an appealing resource. In this sense, open-source genomic databases are important for the development of genetic discoveries and possibly for the implementation of clinical decision-making. For instance, protein-protein interaction (PPI) networks have been used to identify genes that are significant in the context of such associations [30-36].

To this end, we aimed to develop a PPI network between known genes where single nucleotide polymorphisms (SNPs) produce protein variants strongly associated with PD and periodontitis onset, to identify potential biological mechanisms of interaction. Furthermore, we tested the blood-brain barrier permeability of proteins derived from the developed PPI network, to investigate the possibility of moving into the brain.

\section{Materials and Methods}

\subsection{Data Source}

We searched The National Human Genome Research Institute-European Bioinformatics Institute Catalog of human Genome-Wide Association Studies (NHGRI-GWAS) for PD and periodontitis associated SNPs [37]. This a comprehensive catalogue of reported associations from published Genome-Wide Association Studies (GWAS). We used a publicly available summary statistics dataset from periodontitis GWAS performed in up to 100,903 individuals of European, Asian, American and other ancestries [38-50] (Table S1).

For Parkinson's disease, we used a summary statistics dataset from periodontitis GWAS performed in up to 1,640,901 individuals of European, Asian, American, Sub-Saharan African and other ancestries [51-88] (Table S2). GWAS datasets for both PD and periodontitis were derived from different populations, as there are no GWAS data combining both conditions.

\subsection{Protein-Protein Interaction Networks Functional Enrichment Analysis}

The STRING (Search Tool for the Retrieval of Interacting Genes/Proteins) database, complemented with heuristic methods of association and analysis, was used to investigate known and predicted PPI association for both PD and Periodontitis. The STRING database generates a network of PPI from high-throughput experimental data, literature and predictions based on genomic context analysis $[89,90]$. The interactions in STRING are sourced from five main sources: Genomic Context Predictions, High-throughput Lab Experiments, (Conserved) Co-Expression, Automated Text mining and Previous Knowledge in Databases. Protein characteristics were obtained through the Universal Protein Resource [91].

\subsection{Blood-Brain Barrier Permeability Analysis}

Blood-brain barrier permeability was predicted through the protein characteristics presented in the Protein Atlas Database [92]. Protein information (length, mass, prediction as a signal peptide and prediction as transmembrane protein), as well RNA expression within brain tissues, allowed us to foresee the possibility of passing. We assumed that isoforms having a mass equal to or lower than $20 \mathrm{kDa}$ were deemed possible to surpass the blood-brain barrier permeability. Proteins with a mass higher than $20 \mathrm{kDa}$ were assumed to be found at the brain via local expression and secretion. 


\subsection{Data Management, Test Methods and Analysis}

Data were downloaded through the GWAS website and handled with Microsoft Office Excel. PPI network was rendered via STRING database version 10.5. We set the highest confidence cutoff in this interaction analysis (of 0.9 ). Then, a sensitivity analysis with a confidence cutoff of 0.7 was conducted, to investigate whether the results are dependent on the choice of the confidence cutoff. In the resulting PPI network, proteins are presented as nodes which are connected by lines whose thickness represents this confidence level. We also carried out a heatmap of protein interactions, using the 'ggplot' R package.

\subsection{Protein Set Enrichment Analysis}

To investigate the presence of over-representation of some proteins in the obtained network and the possible influence in the observed PPI, we used The Geneontology Resource (http://geneontology.org/). We started by analyzing the "Panther pathways" [93] over the final list of genes in the PPI. Then, we looked over the "Reactome pathways". To calculate the false discovery rate, both annotations were tested through the Fisher's Exact test.

\section{Results}

\subsection{Protein-Protein Interaction Analysis}

Using the STRING online tool, we found 100 nodes with 66 PPI relationships (Figure 1). The properties of the network were analyzed, indicating that the network of PPIs had more interactions among themselves than what would be expected for a random set of proteins of similar size, drawn from the proteome. Such an enrichment indicates that the proteins are, at least, partially biologically connected $\left(p\right.$-value $\left.=1.89 \times 10^{-5}\right)$. From an expected number of 14 edges, it was cast a final number of 33 edges (average node degree $=0.66$; average local clustering coefficient $=0.27$ ). The sensitivity analysis with a confidence cutoff of 0.7 revealed that the results are not dependent on the choice of the confidence cutoff, since the same network emerged.

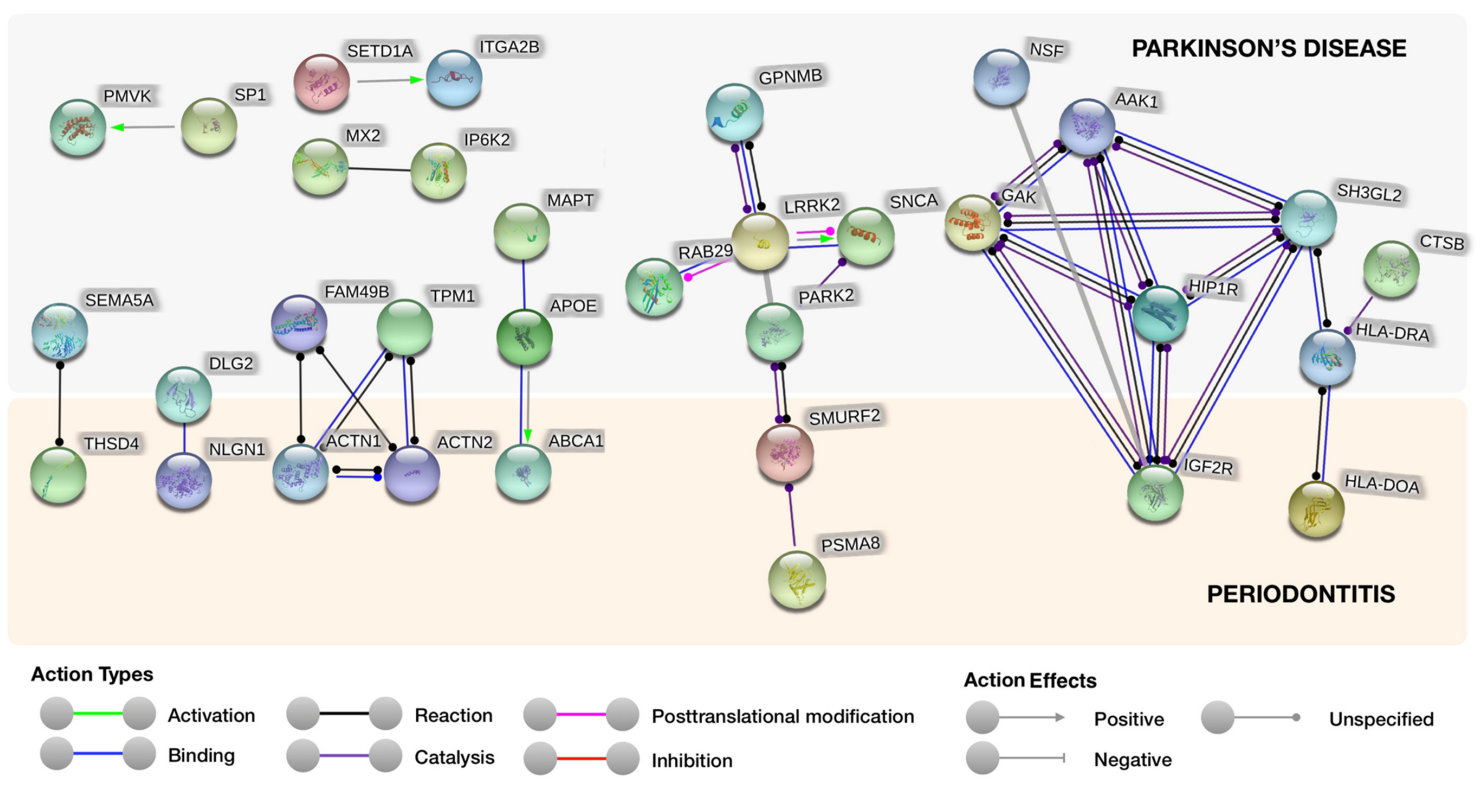

Figure 1. Search Tool for the Retrieval of Interacting Genes/Proteins (STRING) analysis reveals protein interaction networks between Parkinson's disease and periodontitis proteins. We implemented the highest confidence cutoff of 0.9 in this network. In the resulting protein association network, proteins are presented as nodes which are connected by lines whose thickness represents the confidence level (0.9). 
Interestingly, we found possible PPIs between PD's and periodontitis's known associated proteins (Figure 1 and Table 1). The least likely association is between Disks large homolog 2 (DLG2) and Neuroligin-1 (NLGN1) (Score $=0.966$ ), as DLG2 is a common protein for both conditions. The remaining interactions were as follows: Thrombospondin type 1 domain containing protein 4 (THSD4) and Semaphorin 5A (SEMA5A); Actinin $\alpha 1$ (ACTN1) and Actinin $\alpha 2$ (ACTN2) with Family with sequence similarity 49 member B (FAM49B) and Tropomyosin 1 (TPM1); Smad ubiquitination regulatory factor-2 (SMURF2) was establishing a connection between Parkin 2 (PARK2) and Proteasome 20S Subunit $\alpha$ 8 (PSMA8); multiple interactions of insulin-like growth factor 2 receptor (IGF2R) with Huntingtin Interacting Protein 1 Related (HIP1R), Cyclin G-associated kinase (GAK), SF3GL2 and AP2 Associated Kinase 1 (AAK1); HLA class II histocompatibility antigen, DO $\alpha$ chain (HLA-DOA) with HLA class II histocompatibility antigen, and DR $\alpha$ chain (HLA-DRA). Furthermore, we detail the physiological characteristics and localization of each interaction protein (Table 2). We also confirmed protein interaction by using a heatmap plot (Figure 2).

Table 1. Score results between Parkinson's disease (PD) and periodontitis related proteins identified in the network interaction.

\begin{tabular}{ccc}
\hline Proteins for PD (Regulation) & Proteins for Periodontitis (Regulation) & Score \\
\hline TPM1 & ACTN2 & 0.995 \\
DLG2 & NLGN1 & 0.966 \\
TPM1 & ACTN1 & 0.961 \\
APOE & ABCA1 & 0.921 \\
HLA-DRA & HLD-DOA & 0.918 \\
NSF & IGF2R & 0.917 \\
HIP1R & IGF2R & 0.916 \\
GAK & IGF2R & 0.916 \\
SH3GL2 & IGF2R & 0.907 \\
PARK2 & SMURF2 & 0.906 \\
AAK1 & IGF2R & 0.903 \\
SEMA5A & THSD4 & 0.902 \\
FAM49B & ACTN1 & 0.901 \\
FAM49B & ACTN2 & 0.901 \\
\hline
\end{tabular}

\subsection{Hydrophobicity Levels of Proteins of Interest}

THSD4, as an extracellular matrix protein, was deemed a candidate to pass the blood-brain barrier. Four isoforms were reported: THSD4-201, THSD4-202, THSD4-203 and THSD4-207. The isoforms THSD4-201, THSD4-202 and THSD4-203 have no potential to pass the blood-brain barrier due to a large mass $(>20 \mathrm{kDa})$. A potential candidate is the isoform THSD4-207 $(10.7 \mathrm{kDa})$, which is predicted as a membrane protein. Nevertheless, RNA expression revealed significant expression of THSD4 in several brain areas significantly related with PD, indicating that THSD4 may be produced locally rather than transported into the brain (Figure 3).

\subsection{Gene Enrichment Assessment}

The Panther over-representation test revealed no statistically significant results. The analysis under the "Reactome pathways" revealed some over-representation in terms of Plasma Lipoprotein Assembly, Golgi Associated Vesicle Biogenesis, trans-Golgi Network Vesicle Budding, Membrane Trafficking, cargo recognition for clathrin-mediated endocytosis, Clathrin-mediated endocytosis, Platelet degranulation and response to elevated platelet cytosolic Ca2+ (Table S3). 
Table 2. Details of the identified proteins in the interaction between PD and periodontitis.

\begin{tabular}{|c|c|c|c|}
\hline Protein Symbol & Name & Description & Localization \\
\hline \multicolumn{4}{|c|}{ Parkinson's Disease } \\
\hline SEMA5A & Semaphorin-5A & $\begin{array}{l}\text { Bifunctional axonal guidance signal via sulfated proteoglycans } \\
\text { regulation. }\end{array}$ & $\begin{array}{l}\text { - Plasma membrane } \\
\text { - Extracellular exosome }\end{array}$ \\
\hline FAM49B & Protein FAM49B & Family with sequence similarity 49 member B & - Mitochondrion \\
\hline TPM1 & Tropomyosin $\alpha-1$ chain & Tropomyosin 1 & - Cytoskeleton \\
\hline APOE & Apolipoprotein E & $\begin{array}{c}\text { Intermediates catabolic, link, and internalization processes of } \\
\text { lipoprotein particles. }\end{array}$ & - Extracellular region or secreted \\
\hline PARK2 & E3 ubiquitin-protein ligase parkin & $\begin{array}{l}\text { Acts in a multiproteic complex (E3 ubiquitin ligase), catalyzing the } \\
\text { link of proteins-ubiquitin moieties. Intervenes monoubiquitination } \\
\text { as well as 'Lys-6', 'Lys-11', 'Lys- } 48^{\prime} \text {-linked and 'Lys-63'-linked } \\
\text { polyubiquitination of substrates depending on the context. }\end{array}$ & $\begin{array}{l}\text { - Mitochondrion } \\
\text { - Nucleus } \\
\text { - Cytosol } \\
\text { - Endoplasmic reticulum }\end{array}$ \\
\hline HIP1R & $\begin{array}{l}\text { Huntingtin-interacting protein } \\
\text { 1-related protein }\end{array}$ & $\begin{array}{c}\text { Constituent of vesicles and pits coated by clathrin, that may bind } \\
\text { the endocytic apparatus to the actin cytoskeleton. } \\
\text { Binds 3-phosphoinositides (through the ENTH domain). } \\
\text { May uphold cell survival via stabilization of tyrosine kinases } \\
\text { receptor after endocytosis }\end{array}$ & $\begin{array}{l}\text { - Perinuclear } \\
\text { - Endomembrane system } \\
\text { - Clathrin-coated vesicle membrane }\end{array}$ \\
\hline GAK & Cyclin-G-associated kinase & $\begin{array}{l}\text { Is a serine/threonine kinase that links with CDK5 and cyclin G } \\
\text { acting in the cell cycle and focal adhesion }\end{array}$ & $\begin{array}{l}\text { - Golgi apparatus } \\
\text { - Perinuclear region } \\
\text { - Focal adhesion }\end{array}$ \\
\hline AAK1 & AP2-associated protein kinase 1 & $\begin{array}{l}\text { Regulates endocytosis mediated by clathrin-mediated via } \\
\text { AP2M1/mu2 subunit phosphorylation of the adaptor protein } \\
\text { complex 2 (AP-2) fostering high affinity binding of AP-2 to cargo } \\
\text { membrane proteins during the initial stages of endocytosis. }\end{array}$ & $\begin{array}{l}\text { - Plasma membrane } \\
\text { - Clathrin-coated pit } \\
\text { - Presynapse }\end{array}$ \\
\hline SH3GL2 & Endophilin-A1 & Involved in the endocytosis of synaptic vesicles. & $\begin{array}{l}\text { - Endosome } \\
\text { - Cytoplasm } \\
\text { - Membrane } \\
\text { - Presynapse }\end{array}$ \\
\hline CTSB & Cathepsin B & $\begin{array}{c}\text { A Thiol protease that is implicated in intracellular degradation and } \\
\text { proteins turnover. }\end{array}$ & $\begin{array}{l}\text { - Lysosome } \\
\text { - Plasma Membrane } \\
\text { - Extracellular region }\end{array}$ \\
\hline HLA-DRA & $\begin{array}{l}\text { HLA class II histocompatibility } \\
\text { antigen, DR } \alpha \text { chain }\end{array}$ & $\begin{array}{l}\text { Binds antigens' peptides that entree into the endocytic path of } \\
\text { antigen presenting cells and bestows onto the cell surface for } \\
\text { recognition by T-CD } 4 \text { cells. }\end{array}$ & $\begin{array}{l}\text { - Golgi apparatus } \\
\text { - Lysosome } \\
\text { - Plasma membrane } \\
\text { - Endoplasmic reticulum } \\
\text { - Endosome }\end{array}$ \\
\hline
\end{tabular}


Table 2. Cont.

\begin{tabular}{|c|c|c|c|}
\hline Protein Symbol & Name & Description & Localization \\
\hline NSF & Vesicle-fusing ATPase & $\begin{array}{l}\text { Involved in vesicle-mediated transport. Catalyzes the vesicles' } \\
\text { fusion with the Golgi cisternae. Acts as a fusion protein essential in } \\
\text { the delivery of cargo proteins to the Golgi stack. }\end{array}$ & - Cytoplasm \\
\hline \multicolumn{4}{|c|}{ Periodontitis } \\
\hline THSD4 & $\begin{array}{l}\text { Thrombospondin type- } 1 \\
\text { domain-containing protein } 4\end{array}$ & $\begin{array}{l}\text { Promotes the assembly of a FBN1 matrix. } \\
\text { Attenuates TGFB signaling. }\end{array}$ & - Extracellular Matrix \\
\hline NLGN1 & Neuroligin-1 & $\begin{array}{l}\text { Cell surface protein involved in synapses and synaptic signal } \\
\text { transmission, and recruits and clusters other synaptic proteins. }\end{array}$ & $\begin{array}{l}\text { - Extracellular Region } \\
\text { - Plasma membrane } \\
\text { - Post-synaptic density }\end{array}$ \\
\hline ACTN1 & $\alpha$-actinin-1 & Bundling protein of F-actin that anchors actin intracellularly. & $\begin{array}{l}\text { - Plasma membrane } \\
\text { - Cytoskeleton }\end{array}$ \\
\hline ACTN2 & $\alpha$-actinin-2 & Bundling protein of F-actin that anchors actin intracellularly. & - Z line \\
\hline ABCA1 & $\begin{array}{l}\text { ATP-binding cassette sub-family A } \\
\text { member } 1\end{array}$ & Anion transporter dependent on cAMP sensitive to sulfonylurea. & $\begin{array}{l}\text { - Endosome } \\
\text { - Plasma Membrane } \\
\text { - Membrane }\end{array}$ \\
\hline SMURF2 & E3 ubiquitin-protein ligase SMURF2 & $\begin{array}{l}\text { Involved in the transfer of the ubiquitin to targeted substrates. } \\
\text { Interacts with SMAD1 and SMAD7 triggering ubiquitination } \\
\text { and degradation. }\end{array}$ & $\begin{array}{l}\text { - Plasma Membrane } \\
\text { - Nucleus } \\
\text { - Cytoplasm } \\
\text { - Membrane Raft }\end{array}$ \\
\hline IGF2R & $\begin{array}{l}\text { Cation-independent } \\
\text { mannose-6-phosphate receptor }\end{array}$ & $\begin{array}{l}\text { Involved in the transport of phosphorylated lysosomal enzymes } \\
\text { to lysosomes. }\end{array}$ & - Lysosome \\
\hline HLA-DOA & $\begin{array}{l}\text { HLA class II histocompatibility } \\
\text { antigen, } \mathrm{DO} \alpha \text { chain }\end{array}$ & $\begin{array}{c}\text { Modulates the HLA class II restricted antigen displaying path via } \\
\text { the interaction with B-cells' HLA-DM. Alters the peptide } \\
\text { interchange activity of HLA-DM }\end{array}$ & $\begin{array}{l}\text { - Lysosome } \\
\text { - Endosome }\end{array}$ \\
\hline \multicolumn{4}{|c|}{ Parkinson's Disease and Periodontitis } \\
\hline DLG2 & Disks large homolog 2 & $\begin{array}{l}\text { Acts in chronic pain perception via NMDA receptor signaling. } \\
\text { Regulates the stability of cholinergic synapses. }\end{array}$ & $\begin{array}{l}\text { - Plasma membrane } \\
\text { Other locations: } \\
\text { - Postsynaptic density } \\
\text { - Synapse } \\
\text { - Axon } \\
\text { - Perikaryon }\end{array}$ \\
\hline
\end{tabular}




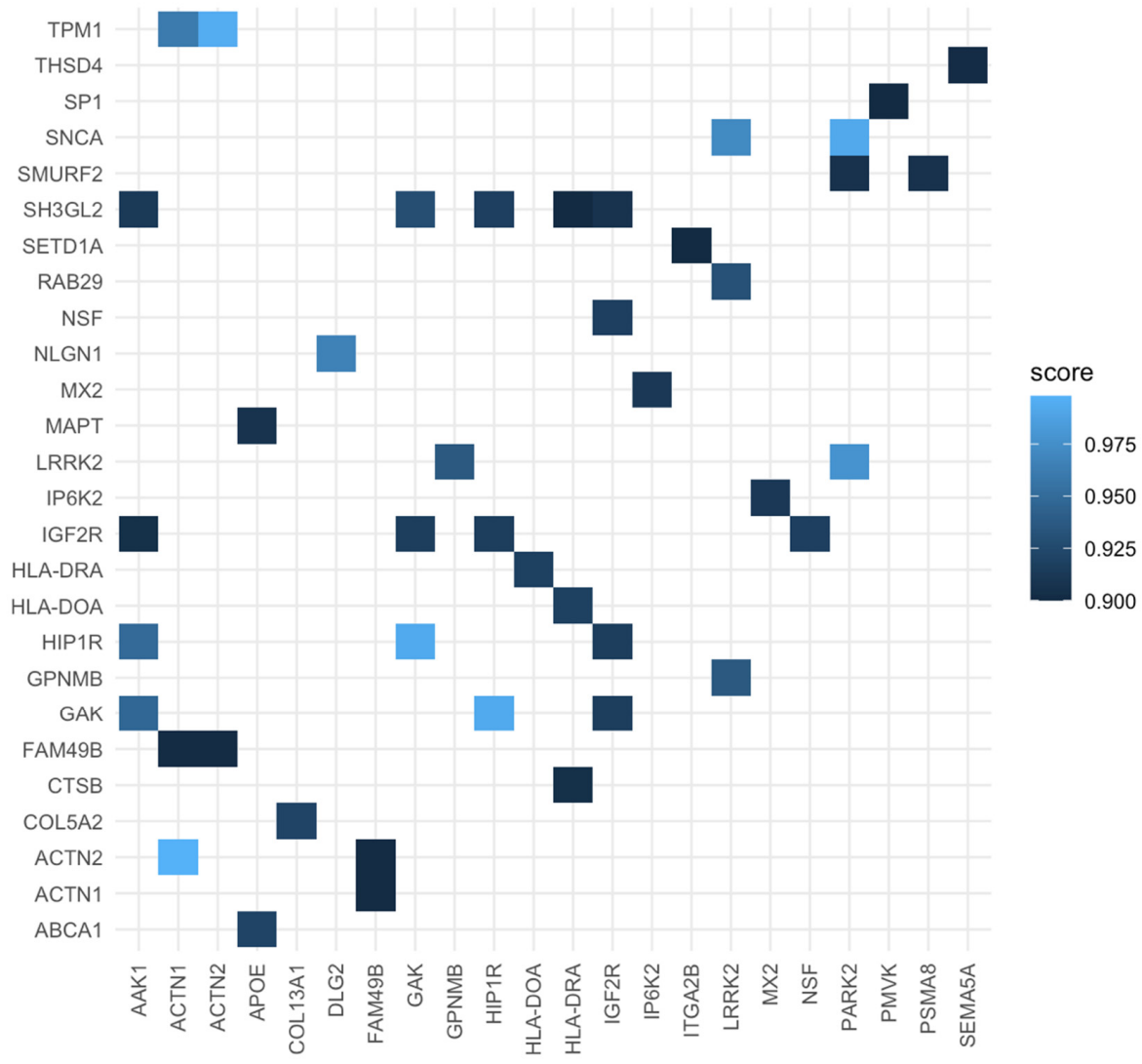

Figure 2. Heatmap of proteins.

Consensus Human brain dataset

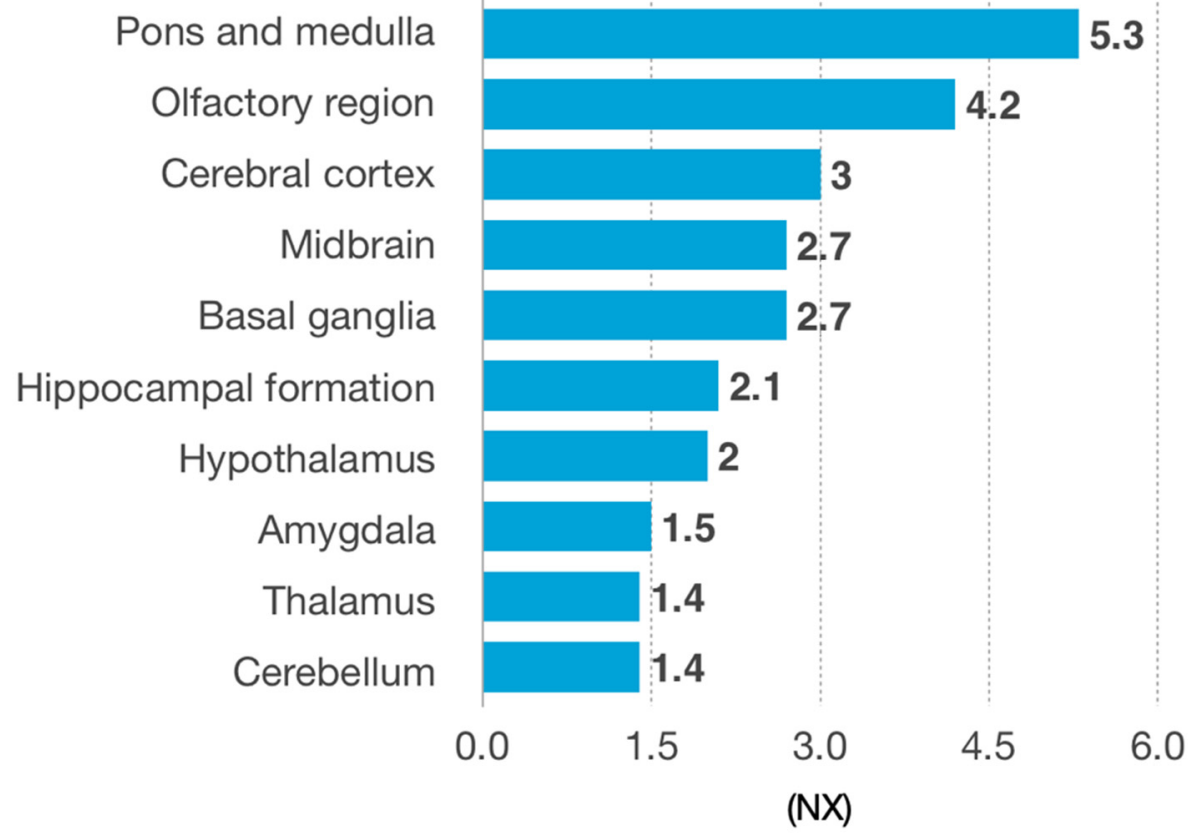

Figure 3. RNA expression of THSD4 gene in different brain regions, according to the Consensus Human Brain Dataset. 


\section{Discussion}

In this bioinformatic study, we predicted a potential PPI network between PD and periodontitis from catalogues of human genome-wide association studies, using a bioinformatic approach. Although these PPIs require further experimental validation, they unravel new clues for downstream studies and propose biological-mechanism pathways through which these two conditions may interplay.

A strong candidate in this study is the interaction established by SMURF2, a E3 ubiquitin-protein ligase which accepts ubiquitin from an E2 ubiquitin-conjugating enzyme in the form of a thioester and then directly transfers the ubiquitin to targeted substrates [94]. According to the obtained network, SMURF2 is proposed to interact with PARK2 (E3 ubiquitin-protein ligase parkin), a protein involved in the pathway protein ubiquitination, and previously associated to pathogenic mechanisms in PD [95,96]. Emerging evidence highlighted the role of impaired ubiquitin phosphorylation-dependent mitophagy and PD pathogenesis and supports multiple potential therapeutic targets for PD drug discovery [97,98].

The proteins IGF2R and HLA-DOA also figured some potential role in this network. IGF2R is a transport of phosphorylated lysosomal enzymes from the Golgi complex and the cell surface to lysosomes, and was linked to proteins located at the plasma membrane (AAK1, SH3GH2), perinuclear region (HIP1E, GAK) and others. Moreover, HLA-DOA, a key modulator in the HLA class II restricted antigen presentation pathway, was linked to HLA-DR that binds peptides derived from antigens that access the endocytic route. Interestingly, both IGF2R and HLA-DOA have never been investigated in periodontal medicine, though these potential interactions mainly in the lysocytic/endocytic pathways should be investigated in regard to the interplay between PD and periodontitis.

In the same way, ABCA1, a cAMP-dependent and sulfonylurea-sensitive anion transporter present in the endosome and plasma membrane also depicted a potential link with APOE that mediates the binding, internalization and catabolism of lipoprotein particles. A recent study showed that oxysterols increased the osteogenic activity of PDLSCs, and the expression of ABCA1 increased significantly during osteogenesis [99]. Moreover, APOE-in particular, its isoform 4-was recently proposed to increase the risk of periodontitis [100], and APOE-2 allele is associated with higher prevalence of sporadic PD [101,102]. Thus, the APOE-ABCA1 pathway might play a role in this relationship, mainly within the catabolism of triglycerides and cholesterol, highly associated with PD and periodontitis.

Additionally, THSD4 revealed a possible link with SEMA5A. THSD4 is a protein present in the extracellular region that is weakly expressed in the early stage dental follicle, but becomes readily detectable in assembled microfibril-like structures during the periodontal ligament-forming stage of the dental follicle and in organized microfibrils in the adult periodontal ligament. Moreover, THSD4 is upregulated in the periodontal ligament during periodontitis wound healing (Manabe et al. 2008). On the other hand, SEMA5A is involved in axonal guidance and, in some conditions, reduces the ability to form connections with other neurons in certain brain areas and is possibly a PD preclinical marker [103-105]. Considering this possible association, we further analyzed if THSD4 had the ability to pass the blood-brain barrier, though the current knowledge is that its isoforms are too large or are membrane-like proteins; however, the possibility of THSD4 transport proteins in the blood-brain barrier cannot be excluded. Still, a considerable expression of THSD4 is reported in several brain areas, particularly in the basal ganglia and midbrain, known to be PD-related areas. Notwithstanding, medulla/olfactory bulbs are proposed as two starting points of PD in the brain, based on the Braak staging proposal [106], and they accounted for the higher accounts of THSD4 RNA. Hence, despite the fact that the areas more commonly known as PD-related (the midbrain and basal ganglia) present significant values, the reader should bear in mind that this protein of interest is present throughout the brain; all of these regions are affected in PD.

The proteins ACTN1 and ACTN2, both f-actin crosslinking proteins thought to anchor actin to a variety of intracellular structures, were linked with FAM49B and TPM1 present in mitochondria and cytoskeleton. 
Furthermore, the protein interaction between HLA-DOA and HLA-DRA may occur through their co-localization at the lysosomal complex; however, the importance for the interaction between these two conditions shall be clarified. The same is expected for the complex IGF2R.

This study presents a powerful and comprehensive analysis from large outputs and large sample size sets. Nevertheless, there are some potential limitations to mention. Firstly, the number of genes represented in GWAS is always dependent on the available number of GWAS studies. Therefore, we anticipate that the increase in GWAS datasets will ultimately unveil new pathways of interaction and disregard previous ones. Another limitation of this study is that we were unable to explore confounding factors, yet the rationale of using GWAS studies is to surpass the environment risk factors load. GWAS research has revolutionized the field of complex disease genetics and has been successful in identifying novel variant-trait associations; this research has limited clinical predictive value [107], but, in our opinion, ignoring these potentially new mechanisms would be unwise. Moreover, the quantity of SNPs of interest in these datasets have combined both European, Asian, African and other populations, which may limit the application of these results. Moreover, the likelihood of finding the number of interactions for each given gene/protein was not possible to clarify, as there are more active genes that may have more interactions, and this should be clarified in future investigations. Despite these limitations, the sample size of this study (over 1.7 million people) makes the results compelling. We have also conducted a protein-enrichment analysis, to look at possible over-representation of influence in the observed PPI.

\section{Conclusions}

Within the limitations of this study, our protein network casts potential protein-protein interactions between Parkinson's disease and periodontitis. Our results may guide future studies in molecular mechanisms between Parkinson's disease and periodontitis and may serve new potential targets for research purposes.

Supplementary Materials: The following are available online at http://www.mdpi.com/2073-4425/11/11/1385/s1, Table S1: Genes expressing protein variants related to Periodontitis, Table S2: Genes expressing protein variants related to Parkinson's Disease, Table S3: Reactome pathways analysis results.

Author Contributions: Conceptualization, J.B.; methodology, J.B., P.M.; validation, P.M.; formal analysis, J.B.; investigation, V.M. and J.B.; data curation, J.B.; writing-original draft preparation, J.B., V.M., P.M. and J.J.M.; writing-review and editing, J.B., V.M., P.M. and J.J.M. All authors have read and agreed to the published version of the manuscript.

Funding: This research received no external funding.

Conflicts of Interest: The authors declare no conflict of interest.

\section{References}

1. Tysnes, O.-B.; Storstein, A. Epidemiology of Parkinson's disease. J. Neural Transm. 2017, 124, 901-905. [CrossRef] [PubMed]

2. Foltynie, T.; Brayne, C.; Barker, R.A. The heterogeneity of idiopathic Parkinson's disease. J. Neurol. 2002, 249, 138-145. [CrossRef] [PubMed]

3. Surmeier, D.J.; Obeso, J.A.; Halliday, G.M. Selective neuronal vulnerability in Parkinson disease. Nat. Rev. Neurosci. 2017, 18, 101-113. [CrossRef]

4. Schrag, A.; Quinn, N.P.; Irving, R.J.; Oram, S.H.; Boyd, J.; Rutledge, P.; Mcrae, F.; Bloomfield, P. Cross sectional prevalence survey of idiopathic Parkinson's disease and parkinsonism in London Ten year audit of secondary prevention in coronary bypass patients. BMJ 2000, 321, 21-22. [PubMed]

5. Alves, G.; Müller, B.; Herlofson, K.; HogenEsch, I.; Telstad, W.; Aarsland, D.; Tysnes, O.-B.; Larsen, J.P.; for the Norwegian ParkWest Study Group. Incidence of Parkinson's disease in Norway: The Norwegian ParkWest study. J. Neurol. Neurosurg. Psychiatry 2009, 80, 851-857. [CrossRef] [PubMed] 
6. Noyce, A.J.; Bandres-Ciga, S.; Kim, J.; Heilbron, K.; Kia, D.; Hemani, G.; Xue, A.; Lawlor, D.A.; Smith, G.D.; Duran, R.; et al. The Parkinson's Disease Mendelian Randomization Research Portal. Mov. Disord. 2019, 34, 1864-1872. [CrossRef]

7. Qiu, X.; Xiao, Y.; Wu, J.; Gan, L.; Huang, Y.; Wang, J. C-Reactive Protein and Risk of Parkinson's Disease: A Systematic Review and Meta-Analysis. Front. Neurol. 2019, 10, 10. [CrossRef]

8. Chen, X.; Hu, Y.; Cao, Z.; Liu, Q.; Cheng, Y. Cerebrospinal Fluid Inflammatory Cytokine Aberrations in Alzheimer's Disease, Parkinson's Disease and Amyotrophic Lateral Sclerosis: A Systematic Review and Meta-Analysis. Front. Immunol. 2018, 9, 2122. [CrossRef]

9. Tonetti, M.; Jepsen, S.; Jin, L.; Otomo-Corgel, J. Impact of the global burden of periodontal diseases on health, nutrition and wellbeing of mankind: A call for global action. J. Clin. Periodontol. 2017, 44, 456-462. [CrossRef] [PubMed]

10. Tonetti, M.S.; Greenwell, H.; Kornman, K.S. Staging and grading of periodontitis: Framework and proposal of a new classification and case definition. J. Periodontol. 2018, 45, S149-S161.

11. Caton, J.G.; Armitage, G.; Berglundh, T.; Chapple, I.L.C.; Jepsen, S.; Kornman, K.S.; Mealey, B.L.; Papapanou, P.N.; Sanz, M.; Tonetti, M.S. A new classification scheme for periodontal and peri-implant diseases and conditions-Introduction and key changes from the 1999 classification. J. Clin. Periodontol. 2018, 45, S1-S8. [PubMed]

12. Southerland, J.H.; Moss, K.; Taylor, G.W.; Beck, J.D.; Pankow, J.; Gangula, P.R.; Offenbacher, S. Periodontitis and diabetes associations with measures of atherosclerosis and CHD. Atherosclerosis 2012, 222, 196-201. [CrossRef] [PubMed]

13. Aguilera, E.M.; Suvan, J.; Buti, J.; Czesnikiewicz-Guzik, M.; Ribeiro, A.B.; Orlandi, M.; Guzik, T.J.; Hingorani, A.D.; Nart, J.; D'Aiuto, F. Periodontitis is associated with hypertension: A systematic review and meta-analysis. Cardiovasc. Res. 2020, 116, 28-39. [CrossRef]

14. Sanz, M.; Del Castillo, A.M.; Jepsen, S.; Gonzalez-Juanatey, J.R.; D’Aiuto, F.; Bouchard, P.; Chapple, I.; Dietrich, T.; Gotsman, I.; Graziani, F.; et al. Periodontitis and cardiovascular diseases: Consensus report. J. Clin. Periodontol. 2020, 47, 268-288. [CrossRef] [PubMed]

15. Kellesarian, S.V.; Malignaggi, V.R.; Kellesarian, T.V.; Al-Kheraif, A.A.; Alwageet, M.M.; Malmstrom, H.; Romanos, G.E.; Javed, F. Association between periodontal disease and polycystic ovary syndrome: A systematic review. Int. J. Impot. Res. 2017, 29, 89-95. [CrossRef] [PubMed]

16. Machado, V.; Escalda, C.; Proença, L.; Mendes, J.J.; Botelho, J. Is There a Bidirectional Association between Polycystic Ovarian Syndrome and Periodontitis? A Systematic Review and Meta-Analysis. J. Clin. Med. 2020, 9, 1961. [CrossRef]

17. Hussain, S.B.; Botelho, J.; Machado, V.; Zehra, S.A.; Mendes, J.J.; Ciurtin, C.; Orlandi, M.; Aiuto, F.D. Is there a bidirectional association between rheumatoid arthritis and periodontitis? A systematic review and meta-analysis. Semin. Arthritis Rheum. 2020, 50, 414-422. [CrossRef]

18. Dominy, S.S.; Lynch, C.; Ermini, F.; Benedyk, M.; Marczyk, A.; Konradi, A.; Nguyen, M.; Haditsch, U.; Raha, D.; Griffin, C.; et al. Porphyromonas gingivalis in Alzheimer's disease brains: Evidence for disease causation and treatment with small-molecule inhibitors. Sci. Adv. 2019, 5, eaau3333. [CrossRef]

19. Hashioka, S.; Inoue, K.; Miyaoka, T.; Hayashida, M.; Wake, R.; Oh-Nishi, A.; Inagaki, M. The Possible Causal Link of Periodontitis to Neuropsychiatric Disorders: More Than Psychosocial Mechanisms. Int. J. Mol. Sci. 2019, 20, 3723. [CrossRef]

20. Dioguardi, M.; Crincoli, V.; Laino, L.; Alovisi, M.; Sovereto, D.; Mastrangelo, F.; Russo, L.L.; Muzio, L.L. The Role of Periodontitis and Periodontal Bacteria in the Onset and Progression of Alzheimer's Disease: A Systematic Review. J. Clin. Med. 2020, 9, 495. [CrossRef]

21. Kaur, T.; Uppoor, A.; Naik, D. Parkinson's disease and periodontitis-The missing link? A review. Gerodontology 2015, 33, 434-438. [CrossRef]

22. Lyra, P.; Machado, V.; Proença, L.; Domingos, J.; Godinho, C.; Mendes, J.J.; Botelho, J. Parkinson's Disease, Periodontitis and Patient-Related Outcomes: A Cross-Sectional Study. Medicina 2020, 56, 383. [CrossRef]

23. Schwarz, J.; Heimhilger, E.; Storch, A. Increased periodontal pathology in Parkinson's disease. J. Neurol. 2006, 253, 608-611. [CrossRef]

24. Einarsdóttir, E.R.; Gunnsteinsdóttir, H.; Hallsdóttir, M.H.; Sveinsson, S.; Jónsdóttir, S.R.; Olafsson, V.G.; Bragason, T.H.; Saemundsson, S.R.; Holbrook, W.P.; Sæmundsson, S.R. Dental health of patients with Parkinson's disease in Iceland. Spéc. Care Dent. 2009, 29, 123-127. [CrossRef] 
25. Hanaoka, A.; Kashihara, K. Increased frequencies of caries, periodontal disease and tooth loss in patients with Parkinson's disease. J. Clin. Neurosci. 2009, 16, 1279-1282. [CrossRef] [PubMed]

26. Nakayama, Y.; Washio, M.; Mori, M. Oral health conditions in patients with Parkinson's disease. J. Epidemiol. 2004, 14, 143-150. [CrossRef] [PubMed]

27. Van Stiphout, M.A.E.; Marinus, J.; Van Hilten, J.J.; Lobbezoo, F.; De Baat, C. Oral Health of Parkinson's Disease Patients: A Case-Control Study. Park. Dis. 2018, 2018, 9315285. [CrossRef]

28. Botelho, J.; Lyra, P.; Proença, L.; Godinho, C.; Mendes, J.J.; Machado, V. Relationship between Blood and Standard Biochemistry Levels with Periodontitis in Parkinson's Disease Patients: Data from the NHANES 2011-2012. J. Pers. Med. 2020, 10, 69. [CrossRef]

29. Chen, C.-K.; Wu, Y.-T.; Chang, Y.-C. Periodontal inflammatory disease is associated with the risk of Parkinson's disease: A population-based retrospective matched-cohort study. PeerJ 2017, 5, e3647. [CrossRef]

30. Salinas-Torres, V.M.; Gallardo-Blanco, H.L.; Salinas-Torres, R.A.; Cerda-Flores, R.M.; Lugo-Trampe, J.J.; Villarreal-Martínez, D.Z.; De Villarreal, L.E.M. Bioinformatic Analysis of Gene Variants from Gastroschisis Recurrence Identifies Multiple Novel Pathogenetic Pathways: Implication for the Closure of the Ventral Body Wall. Int. J. Mol. Sci. 2019, 20, 2295. [CrossRef]

31. Li, Y.; Jiang, Q.; Ding, Z.; Liu, G.; Yu, P.; Jiang, G.; Yu, Z.; Yang, C.; Qian, J.; Jiang, H.; et al. Identification of a Common Different Gene Expression Signature in Ischemic Cardiomyopathy. Genes 2018, 9, 56. [CrossRef]

32. Salazar, C.; Ruiz-Hincapie, P.; Ruiz, L. The Interplay among PINK1/PARKIN/Dj-1 Network during Mitochondrial Quality Control in Cancer Biology: Protein Interaction Analysis. Cells 2018, 7, 154.

33. Wei, L.K.; Quan, L.S. Biomarkers for ischemic stroke subtypes: A protein-protein interaction analysis. Comput. Biol. Chem. 2019, 83, 107116. [CrossRef]

34. Bhyan, S.B.; Zhao, L.; Wee, Y.; Liu, Y.; Zhao, M. Genetic links between endometriosis and cancers in women. PeerJ 2019, 7, e8135. [CrossRef]

35. Pan, Y.; Liu, J.; Qi, F.-Z. Identification of key candidate genes and molecular pathways in white fat browning: An anti-obesity drug discovery based on computational biology. Hum. Genom. 2019, 13, 55. [CrossRef]

36. Zhang, Y.; Ho, K.; Keaton, J.M.; Hartzel, D.N.; Day, F.; Justice, A.E.; Josyula, N.S.; Pendergrass, S.A.; Actkins, K.; Davis, L.K.; et al. A genome-wide association study of polycystic ovary syndrome identified from electronic health records. Am. J. Obstet. Gynecol. 2020. [CrossRef]

37. NHGRI-GWAS NHGRI-GWAS. Available online: https://www.ebi.ac.uk/gwas (accessed on 9 June 2020).

38. Schaefer, A.S.; Richter, G.M.; Nothnagel, M.; Manke, T.; Dommisch, H.; Jacobs, G.; Arlt, A.; Rosenstiel, P.; Noack, B.; Groessner-Schreiber, B.; et al. A genome-wide association study identifies GLT6D1 as a susceptibility locus for periodontitis. Hum. Mol. Genet. 2009, 19, 553-562. [CrossRef]

39. Divaris, K.; Monda, K.; North, K.; Olshan, A.; Lange, E.; Moss, K.; Barros, S.; Beck, J.; Offenbacher, S. Genome-wide Association Study of Periodontal Pathogen Colonization. J. Dent. Res. 2012, 91, S21-S28. [CrossRef]

40. Divaris, K.; Monda, K.L.; North, K.E.; Olshan, A.F.; Reynolds, L.M.; Hsueh, W.-C.; Lange, E.M.; Moss, K.; Barros, S.P.; Weyant, R.J.; et al. Exploring the genetic basis of chronic periodontitis: A genome-wide association study. Hum. Mol. Genet. 2013, 22, 2312-2324. [CrossRef]

41. Teumer, A.; Holtfreter, B.; Völker, U.; Petersmann, A.; Nauck, M.; Biffar, R.; Völzke, H.; Kroemer, H.K.; Meisel, P.; Homuth, G.; et al. Genome-wide association study of chronic periodontitis in a general German population. J. Clin. Periodontol. 2013, 40, 977-985. [CrossRef] [PubMed]

42. Feng, P.; Wang, X.; Casado, P.L.; Küchler, E.C.; Deeley, K.; Noel, J.; Kimm, H.; Kim, J.-H.; Haas, A.N.; Quinelato, V.; et al. Genome wide association scan for chronic periodontitis implicates novel locus. BMC Oral Health 2014, 14, 84. [CrossRef] 
43. Freitag-Wolf, S.; Dommisch, H.; Graetz, C.; Jockel-Schneider, Y.; Harks, I.; Staufenbiel, I.; Meyle, J.; Eickholz, P.; Noack, B.; Bruckmann, C.; et al. Genome-wide exploration identifies sex-specific genetic effects of alleles upstreamNPYto increase the risk of severe periodontitis in men. J. Clin. Periodontol. 2014, 41, 1115-1121. [CrossRef]

44. Freitag-Wolf, S.; Munz, M.; Wiehe, R.; Junge, O.; Graetz, C.; Jockel-Schneider, Y.; Staufenbiel, I.; Bruckmann, C.; Lieb, W.; Franke, A.; et al. Smoking Modifies the Genetic Risk for Early-Onset Periodontitis. J. Dent. Res. 2019, 98, 1332-1339. [CrossRef]

45. Shaffer, J.R.; Polk, D.E.; Wang, X.; Feingold, E.; Weeks, D.E.; Lee, M.-K.; Cuenco, K.T.; Weyant, R.J.; Crout, R.J.; McNeil, D.W.; et al. Genome-Wide Association Study of Periodontal Health Measured by Probing Depth in Adults Ages 18-49 years. G3 Genes Genomes Genet. 2014, 4, 307-314. [CrossRef] [PubMed]

46. Shungin, D.; Haworth, S.; Divaris, K.; Agler, C.S.; Kamatani, Y.; Lee, M.K.; Grinde, K.; Hindy, G.; Alaraudanjoki, V.; Pesonen, P.; et al. Genome-wide analysis of dental caries and periodontitis combining clinical and self-reported data. Nat. Commun. 2019, 10,1-13. [CrossRef]

47. Shimizu, S.; Momozawa, Y.; Takahashi, A.; Nagasawa, T.; Ashikawa, K.; Terada, Y.; Izumi, Y.; Kobayashi, H.; Tsuji, M.; Kubo, M.; et al. A Genome-wide Association Study of Periodontitis in a Japanese Population. J. Dent. Res. 2015, 94, 555-561. [CrossRef] [PubMed]

48. Munz, M.; Willenborg, C.; Richter, G.M.; Jockel-Schneider, Y.; Graetz, C.; Staufenbiel, I.; Wellmann, J.; Berger, K.; Krone, B.; Hoffmann, P.; et al. A genome-wide association study identifies nucleotide variants at SIGLEC5 and DEFA1A3 as risk loci for periodontitis. Hum. Mol. Genet. 2017, 26, 2577-2588. [CrossRef]

49. Bevilacqua, L.; Navarra, C.O.; Pirastu, N.; Di Lenarda, R.; Gasparini, P.; Robino, A. A genome-wide association study identifies an association between variants in EFCAB4B gene and periodontal disease in an Italian isolated population. J. Periodontal Res. 2018, 53, 992-998. [CrossRef]

50. Munz, M.; Richter, G.M.; Loos, B.G.; Jepsen, S.; Divaris, K.; Offenbacher, S.; Teumer, A.; Holtfreter, B.; Kocher, T.; Bruckmann, C.; et al. Meta-analysis of genome-wide association studies of aggressive and chronic periodontitis identifies two novel risk loci. Eur. J. Hum. Genet. 2018, 27, 102-113. [CrossRef]

51. Nalls, M.A.; Keller, M.F.; Hernandez, D.G.; Chen, L.; Stone, D.J.; Singleton, A.B.; on behalf of the Parkinson's Progression Marker Initiative (PPMI) investigators. Baseline genetic associations in the Parkinson's Progression Markers Initiative (PPMI). Mov. Disord. 2016, 31, 79-85. [CrossRef]

52. Hernandez, D.G.; Nalls, M.A.; Ylikotila, P.; Keller, M.; Hardy, J.A.; Majamaa, K.; Singleton, A.B. Genome Wide Assessment of Young Onset Parkinson's Disease from Finland. PLoS ONE 2012, 7, e41859. [CrossRef]

53. Wallen, Z.D.; Chen, H.; Hill-Burns, E.M.; Factor, S.A.; Zabetian, C.P.; Payami, H. Plasticity-related gene 3 (LPPR1) and age at diagnosis of Parkinson disease. Neurol. Genet. 2018, 4, e271. [CrossRef] [PubMed]

54. Fung, H.-C.; Scholz, S.; Matarin, M.; Simón-Sánchez, J.; Hernandez, D.; Britton, A.; Gibbs, J.R.; Langefeld, C.; Stiegert, M.L.; Schymick, J.; et al. Genome-wide genotyping in Parkinson's disease and neurologically normal controls: First stage analysis and public release of data. Lancet Neurol. 2006, 5, 911-916. [CrossRef] [PubMed]

55. Maraganore, D.M.; De Andrade, M.; Lesnick, T.G.; Strain, K.J.; Farrer, M.J.; Rocca, W.A.; Pant, P.V.K.; Frazer, K.A.; Cox, D.R.; Ballinger, D.G. High-Resolution Whole-Genome Association Study of Parkinson Disease. Am. J. Hum. Genet. 2005, 77, 685-693. [CrossRef]

56. Pankratz, N.; Wilk, J.B.; Latourelle, J.C.; DeStefano, A.L.; Halter, C.; Pugh, E.W.; Doheny, K.F.; Gusella, J.F.; Nichols, W.C.; Foroud, T.; et al. Genomewide association study for susceptibility genes contributing to familial Parkinson disease. Qual. Life Res. 2009, 124, 593-605. [CrossRef]

57. Chung, S.J.; Armasu, S.M.; Biernacka, J.M.; Anderson, K.J.; Lesnick, T.G.; Rider, D.N.; Cunningham, J.M.; Ahlskog, J.E.; Frigerio, R.; Maraganore, D.M. Genomic determinants of motor and cognitive outcomes in Parkinson's disease. Park. Relat. Disord. 2012, 18, 881-886. [CrossRef]

58. Biernacka, J.M.; Chung, S.J.; Armasu, S.M.; Anderson, K.S.; Lill, C.M.; Bertram, L.; Ahlskog, J.; Brighina, L.; Frigerio, R.; Maraganore, D.M. Genome-wide gene-environment interaction analysis of pesticide exposure and risk of Parkinson's disease. Park. Relat. Disord. 2016, 32, 25-30. [CrossRef]

59. Hill-Burns, E.M.; Wissemann, W.T.; Hamza, T.H.; Factor, S.A.; Zabetian, C.P.; Payami, H. Identification of a novel Parkinson's disease locus via stratified genome-wide association study. BMC Genom. 2014, 15, 118. [CrossRef]

60. Simón-Sánchez, J.; Van Hilten, J.J.; Van De Warrenburg, B.C.; Post, B.; Berendse, H.W.; Arepalli, S.; Hernandez, D.G.; De Bie, R.M.A.; Velseboer, D.C.; Scheffer, H.; et al. Genome-wide association study confirms extant PD risk loci among the Dutch. Eur. J. Hum. Genet. 2011, 19, 655-661. [CrossRef] 
61. Liu, X.; Cheng, R.; Verbitsky, M.; Kisselev, S.; Browne, A.; Mejia-Sanatana, H.; Louis, E.D.; Cote, L.J.; Andrews, H.F.; Waters, C.H.; et al. Genome-Wide association study identifies candidate genes for Parkinson's disease in an Ashkenazi Jewish population. BMC Med. Genet. 2011, 12, 104. [CrossRef]

62. Davis, M.F.; Cummings, A.C.; D'Aoust, L.N.; Jiang, L.; Edwards, D.R.V.; Laux, R.; Reinhart-Mercer, L.; Fuzzell, D.; Scott, W.K.; Pericak-Vance, M.A.; et al. Parkinson disease loci in the mid-western Amish. Qual. Life Res. 2013, 132, 1213-1221. [CrossRef]

63. Gan-Or, Z.; Amshalom, I.; Bar-Shira, A.; Gana-Weisz, M.; Mirelman, A.; Marder, K.; Bressman, S.; Giladi, N.; Orr-Urtreger, A. The Alzheimer disease BIN1 locus as a modifier of GBA-associated Parkinson disease. J. Neurol. 2015, 262, 2443-2447. [CrossRef] [PubMed]

64. Hill-Burns, E.M.; A Ross, O.; Wissemann, W.T.; Soto-Ortolaza, A.I.; Zareparsi, S.; Siuda, J.; Lynch, T.; Wszolek, Z.K.; Silburn, P.A.; Mellick, G.D.; et al. Identification of genetic modifiers of age-at-onset for familial Parkinson's disease. Hum. Mol. Genet. 2016, 25, 3849-3862. [CrossRef] [PubMed]

65. Nalls, M.A.; Plagnol, V.; Hernandez, D.G.; Sharma, M.; Sheerin, U.-M.; Saad, M.H.F.; Simonsanchez, J.; Schulte, C.; Lesage, S.; Sveinbjornsdottir, S.; et al. Imputation of sequence variants for identification of genetic risks for Parkinson's disease: A meta-analysis of genome-wide association studies. Lancet 2011, 377, 641-649. [CrossRef]

66. Saad, M.; Lesage, S.; Saint-Pierre, A.; Corvol, J.-C.; Zelenika, D.; Lambert, J.-C.; Vidailhet, M.; Mellick, G.D.; Lohmann, E.; Durif, F.; et al. Genome-wide association study confirms BST1 and suggests a locus on $12 \mathrm{q} 24$ as the risk loci for Parkinson's disease in the European population. Hum. Mol. Genet. 2010, 20, 615-627. [CrossRef

67. Hamza, T.H.; Zabetian, C.P.; Tenesa, A.; Laederach, A.; Montimurro, J.; Yearout, D.; Kay, D.M.; Doheny, K.F.; Paschall, J.; Pugh, E.; et al. Common genetic variation in the HLA region is associated with late-onset sporadic Parkinson's disease. Nat. Genet. 2010, 42, 781-785. [CrossRef]

68. Satake, W.; Nakabayashi, Y.; Mizuta, I.; Hirota, Y.; Ito, C.; Kubo, M.; Kawaguchi, T.; Tsunoda, T.; Watanabe, M.; Takeda, A.; et al. Genome-wide association study identifies common variants at four loci as genetic risk factors for Parkinson's disease. Nat. Genet. 2009, 41, 1303-1307. [CrossRef]

69. Edwards, T.L.; Scott, W.K.; Almonte, C.; Burt, A.; Powell, E.H.; Beecham, G.W.; Wang, L.; Züchner, S.; Konidari, I.; Wang, G.; et al. Genome-Wide Association Study Confirms SNPs inSNCAand theMAPTRegion as Common Risk Factors for Parkinson Disease. Ann. Hum. Genet. 2010, 74, 97-109. [CrossRef]

70. Do, C.B.; Tung, J.Y.; Dorfman, E.; Kiefer, A.K.; Drabant, E.M.; Francke, U.; Mountain, J.L.; Goldman, S.M.; Tanner, C.M.; Langston, J.W.; et al. Web-Based Genome-Wide Association Study Identifies Two Novel Loci and a Substantial Genetic Component for Parkinson's Disease. PLoS Genet. 2011, 7, e1002141. [CrossRef]

71. Hamza, T.H.; Chen, H.; Hill-Burns, E.M.; Rhodes, S.L.; Montimurro, J.; Kay, D.M.; Tenesa, A.; Kusel, V.I.; Sheehan, P.; Eaaswarkhanth, M.; et al. Genome-Wide Gene-Environment Study Identifies Glutamate Receptor Gene GRIN2A as a Parkinson's Disease Modifier Gene via Interaction with Coffee. PLoS Genet. 2011, 7, e1002237. [CrossRef]

72. Vacic, V.; Ozelius, L.J.; Clark, L.N.; Bar-Shira, A.; Gana-Weisz, M.; Gurevich, T.; Gusev, A.; Kedmi, M.; Kenny, E.E.; Liu, X.; et al. Genome-wide mapping of IBD segments in an Ashkenazi PD cohort identifies associated haplotypes. Hum. Mol. Genet. 2014, 23, 4693-4702. [CrossRef] [PubMed]

73. Latourelle, J.C.; Pankratz, N.; Dumitriu, A.; Wilk, J.B.; Goldwurm, S.; Pezzoli, G.; Mariani, C.B.; DeStefano, A.L.; Halter, C.; Gusella, J.F.; et al. Genomewide association study for onset age in Parkinson disease. BMC Med Genet. 2009, 10, 98. [CrossRef]

74. Hu, Y.; Deng, L.; Zhang, J.; Fang, X.; Mei, P.; Cao, X.; Lin, J.; Wei, Y.; Zhang, X.; Xu, R. A Pooling Genome-Wide Association Study Combining a Pathway Analysis for Typical Sporadic Parkinson's Disease in the Han Population of Chinese Mainland. Mol. Neurobiol. 2015, 53, 4302-4318. [CrossRef] [PubMed]

75. Pickrell, J.K.; Berisa, T.; Liu, J.Z.; Ségurel, L.; Tung, J.Y.; Hinds, D.A. Detection and interpretation of shared genetic influences on 42 human traits. Nat. Genet. 2016, 48, 709-717. [CrossRef]

76. Blauwendraat, C.; Heilbron, K.; Msc, C.L.V.; Bandres-Ciga, S.; Von Coelln, R.; Pihlstrøm, L.; Simón-Sánchez, J.; Schulte, C.; Sharma, M.; Msc, L.K.; et al. Parkinson's disease age at onset genome-wide association study: Defining heritability, genetic loci, and $\alpha$-synuclein mechanisms. Mov. Disord. 2019, 34, 866-875. [CrossRef]

77. Blauwendraat, C.; Reed, X.; Krohn, L.; Heilbron, K.; Bandres-Ciga, S.; Tan, M.M.; Gibbs, J.R.; Hernandez, D.G.; Kumaran, R.; Langston, R.; et al. Genetic modifiers of risk and age at onset in GBA associated Parkinson's disease and Lewy body dementia. Brain 2020, 143, 234-248. [CrossRef] 
78. Beecham, G.W.; Dickson, D.W.; Scott, W.K.; Martin, E.R.; Schellenberg, G.; Nuytemans, K.; Larson, E.B.; Buxbaum, J.D.; Trojanowski, J.Q.; Van Deerlin, V.M.; et al. PARK10 is a major locus for sporadic neuropathologically confirmed Parkinson disease. Neurology 2015, 84, 972-980. [CrossRef]

79. Lill, C.M.; Roehr, J.T.; McQueen, M.B.; Kavvoura, F.K.; Bagade, S.; Schjeide, B.-M.M.; Schjeide, L.M.; Meissner, E.; Zauft, U.; Allen, N.C.; et al. Comprehensive Research Synopsis and Systematic Meta-Analyses in Parkinson's Disease Genetics: The PDGene Database. PLoS Genet. 2012, 8, e1002548. [CrossRef]

80. Spencer, C.C.A.; Plagnol, V.; Strange, A.; Gardner, M.; Paisan-Ruiz, C.; Band, G.; Barker, R.A.; Bellenguez, C.; Bhatia, K.; Blackburn, H.; et al. Dissection of the genetics of Parkinson's disease identifies an additional association 5' of SNCA and multiple associated haplotypes at 17q21. Hum. Mol. Genet. 2011, 20, 345-353.

81. Pankratz, N.; Beecham, G.W.; DeStefano, A.L.; Dawson, T.M.; Doheny, K.F.; Do, S.A.F.; Hamza, T.H.; Hung, A.Y.; Hyman, B.T.; Ivinson, A.J.; et al. Meta-analysis of Parkinson's Disease: Identification of a novel locus, RIT2. Ann. Neurol. 2012, 71, 370-384. [CrossRef]

82. Foo, J.N.; Tan, L.C.; Irwan, I.D.; Au, W.-L.; Low, H.Q.; Prakash, K.-M.; Annuar, A.A.; Bei, J.; Chan, A.Y.; Chen, C.-M.; et al. Genome-wide association study of Parkinson's disease in East Asians. Hum. Mol. Genet. 2016, 26, 226-232. [CrossRef]

83. Foo, J.N.; Chew, E.G.Y.; Chung, S.J.; Peng, R.; Blauwendraat, C.; Nalls, M.A.; Mok, K.Y.; Satake, W.; Toda, T.; Chao, Y.; et al. Identification of Risk Loci for Parkinson Disease in Asians and Comparison of Risk Between Asians and Europeans. JAMA Neurol. 2020, 77, 746. [CrossRef] [PubMed]

84. Chang, D.; Nalls, M.A.; Hallgrímsdóttir, I.B.; Hunkapiller, J.; Van Der Brug, M.; Cai, F.; Kerchner, G.A.; Ayalon, G.; Bingol, B.; Sheng, M.; et al. A meta-analysis of genome-wide association studies identifies 17 new Parkinson's disease risk loci. Nat. Genet. 2017, 49, 1511-1516. [CrossRef] [PubMed]

85. Bandrés-Ciga, S.; Ahmed, S.; Sabir, M.S.; Blauwendraat, C.; Adarmes-Gómez, A.D.; Msc, I.B.; Msc, M.B.; Msc, D.B.; Carrillo, F.; Msc, M.C.; et al. The Genetic Architecture of Parkinson Disease in Spain: Characterizing Population-Specific Risk, Differential Haplotype Structures, and Providing Etiologic Insight. Mov. Disord. 2019, 34, 1851-1863. [CrossRef] [PubMed]

86. Nalls, M.A.; Pankratz, N.; Lill, C.M.; Do, C.B.; Hernandez, D.G.; Saad, M.; DeStefano, A.L.; Kara, E.; Bras, J.; Sharma, M.; et al. Large-scale meta-analysis of genome-wide association data identifies six new risk loci for Parkinson's disease. Nat. Genet. 2014, 46, 989-993. [CrossRef] [PubMed]

87. Pottier, C.; Zhou, X.; Perkerson, R.B.; Baker, M.; Jenkins, G.D.; Serie, D.J.; Ghidoni, R.; Benussi, L.; Binetti, G.; De Munain, A.L.; et al. Potential genetic modifiers of disease risk and age at onset in patients with frontotemporal lobar degeneration and GRN mutations: A genome-wide association study. Lancet Neurol. 2018, 17, 548-558. [CrossRef]

88. Trochet, H.; Pirinen, M.; Band, G.; Jostins, L.; McVean, G.; Spencer, C.C.A. Bayesian meta-analysis across genome-wide association studies of diverse phenotypes. Genet. Epidemiol. 2019, 43, 532-547. [CrossRef] [PubMed]

89. Szklarczyk, D.; Franceschini, A.; Kuhn, M.; Simonovic, M.; Roth, A.; Minguez, P.; Doerks, T.; Stark, M.; Muller, J.; Bork, P.; et al. The STRING database in 2011: Functional interaction networks of proteins, globally integrated and scored. Nucleic Acids Res. 2011, 39, D561-D568. [CrossRef]

90. STRING-Functional Protein Association Networks. Available online: http://string-db.org/ (accessed on 28 March 2020).

91. Uniprot Data Base. Available online: http://www.uniprot.org/ (accessed on 10 October 2012).

92. Atlas, P. Protein Atlas. Available online: https://www.proteinatlas.org/ (accessed on 15 June 2020).

93. Mi, H.; Muruganujan, A.; Huang, X.; Ebert, D.; Mills, C.; Guo, X.; Thomas, P.D. Protocol Update for large-scale genome and gene function analysis with the PANTHER classification system (v.14.0). Nat. Protoc. 2019, 14, 703-721. [CrossRef]

94. Bonni, S.; Wang, H.-R.; Causing, C.G.; Kavsak, P.; Stroschein, S.L.; Luo, K.; Wrana, J.L. TGF- $\beta$ induces assembly of a Smad2-Smurf2 ubiquitin ligase complex that targets SnoN for degradation. Nat. Cell Biol. 2001, 3, 587-595. [CrossRef]

95. Harper, J.W.; Ordureau, A.; Heo, J.M. Building and decoding ubiquitin hains for mitophagy. Nat. Rev. Mol. Cell Biol. 2018, 19, 93-108. [PubMed]

96. Bonello, F.; Hassoun, S.M.; Mouton-Liger, F.; Shin, Y.S.; Muscat, A.; Tesson, C.; Lesage, S.; Beart, P.M.; Brice, A.; Krupp, J.; et al. LRRK2 impairs PINK1/Parkin-dependent mitophagy via its kinase activity: Pathologic insights into Parkinson's disease. Hum. Mol. Genet. 2019, 28, 1645-1660. [CrossRef] [PubMed] 
97. Chin, L.-S.; Li, L. Ubiquitin phosphorylation in Parkinson's disease: Implications for pathogenesis and treatment. Transl. Neurodegener. 2016, 5, 1-8. [CrossRef] [PubMed]

98. Qiu, S.; Zhu, S.; Xu, S.; Han, Y.; Liu, W.; Zuo, J. Molecular dynamics simulations of human E3 ubiquitin ligase Parkin. Mol. Med. Rep. 2017, 16, 4561-4568. [CrossRef]

99. Lee, J.-S.; Kim, E.; Han, S.; Kang, K.L.; Heo, J.S. Evaluating the oxysterol combination of 22(S)-hydroxycholesterol and 20(S)-hydroxycholesterol in periodontal regeneration using periodontal ligament stem cells and alveolar bone healing models. Stem Cell Res. Ther. 2017, 8, 276. [CrossRef] [PubMed]

100. Pereira, L.; Nascimento, J.; Rêgo, J.; Canuto, K.; Crespo-López, M.E.; Leite, J.I.A.; Baysan, A.; Oriá, R.B. Apolipoprotein E, periodontal disease and the risk for atherosclerosis: A review. Arch. Oral Biol. 2019, 98, 204-212. [CrossRef]

101. Fagan, E.S.; Pihlstrøm, L. Genetic risk factors for cognitive decline in Parkinson's disease: A review of the literature. Eur. J. Neurol. 2017, 24, 561-e20. [CrossRef]

102. Huang, X.; Chen, P.C.; Poole, C. APOE- $\varepsilon 2$ allele associated with higher pevalence of sporadic Parkinson disease. Neurology 2004, 62, 2198-2202.

103. Clarimon, J.; Scholz, S.; Fung, H.-C.; Hardy, J.; Eerola, J.; Hellström, O.; Chen, C.-M.; Wu, Y.-R.; Tienari, P.J.; Singleton, A. Conflicting Results Regarding the Semaphorin Gene (SEMA5A) and the Risk for Parkinson Disease To. Am. J. Hum. Genet. 2006, 78, 1082-1083.

104. Ding, H.; Wang, F.; Ding, X.; Song, X.; Lu, X.; Zhang, K.; Xiao, H.; Ye, M.; Chen, J.; Zhang, Q. Association study of semaphorin 5A with risk of Parkinson's disease in a Chinese Han population. Brain Res. 2008, 1245, 126-129. [CrossRef]

105. Lin, L.; Lesnick, T.G.; Maraganore, D.M.; Isacson, O. Axon guidance and synaptic maintenance: Preclinical markers for neurodegenerative disease and therapeutics. Trends Neurosci. 2009, 32, 142-149. [CrossRef] [PubMed]

106. Braak, H.; Del Tredici, K.; Rüb, U.; De Vos, R.A.; Steur, E.N.J.; Braak, E. Staging of brain pathology related to sporadic Parkinson's disease. Neurobiol. Aging 2003, 24, 197-211. [CrossRef] [PubMed]

107. Tam, V.; Patel, N.; Turcotte, M.; Bossé, Y.; Paré, G.; Meyre, D. Benefits and limitations of genome-wide association studies. Nat. Rev. Genet. 2019, 20, 467-484. [CrossRef] [PubMed]

Publisher's Note: MDPI stays neutral with regard to jurisdictional claims in published maps and institutional affiliations.

(C) 2020 by the authors. Licensee MDPI, Basel, Switzerland. This article is an open access article distributed under the terms and conditions of the Creative Commons Attribution (CC BY) license (http://creativecommons.org/licenses/by/4.0/). 